\title{
Synthesis and molecular docking of isonicotinohydrazide derivatives as anti-tuberculosis candidates
}

\author{
Ruswanto a, c, ${ }^{*}$, Richa Mardianingrum ${ }^{\text {b }}$, Tresna Lestari a , Tita Nofianti a, Nur Rahayuningsih a, c \\ a Department of Pharmacy, Sekolah Tinggi Ilmu Kesehatan Bakti Tunas Husada, Tasikmalaya, Indonesia \\ ${ }^{b}$ Department of Pharmacy, Perjuangan University, Tasikmalaya, Indonesia \\ c Scientific Consortium for Drug Discovery and Development, Faculty of Pharmacy, Universitas Padjadjaran, Bandung, Indonesia
}

*Corresponding author: ruswanto@stikes-bth.ac.id

\section{Article history}

Received 16 February 2018

Revised 16 August 2018

Accepted 3 September 2018

Published Online 25 June 2019

\section{Graphical abstract}

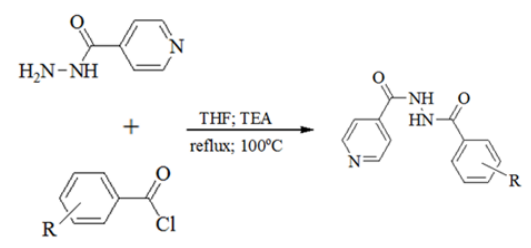

\begin{abstract}
Tuberculosis (TB) is a chronic disease as a result of Mycobacterium tuberculosis. It can affect all age groups, and hence, is a global health problem that causes the death of millions of people every year. One of the drugs used in tuberculosis treatment is isonicotinohydrazide (Isoniazid). In this study, N'benzoylisonicotinohydrazide derivative compounds (a-I) were prepared using acylation reactions between isonicotinohydrazide and benzoyl chloride derivatives, employing the reflux method. Molecular docking studies suggested that all of the compounds had better interaction with Mycobactarium tuberculosis enoyl-acyl carrier protein reductase $(\operatorname{Inh} A)$ than isonicotinohydrazide. It can be concluded that $\mathrm{N}^{\prime}$-benzoylisonicotinohydrazide derivatives (a-I) can be used as antituberculosis candidates. The docking results obtained revealed that all of the compounds were interacted well with InhA, with compound $\mathbf{g}$ exhibiting the best interaction.
\end{abstract}

Keywords: N'-benzoylisonicotinohydrazide, inhibin Alpha Subunit (InhA) inhibition, anti-tuberculosis, synthesis, docking

(C) 2019 Penerbit UTM Press. All rights reserved

\section{INTRODUCTION}

Tuberculosis (TB) is a chronic disease as a result of Mycobacterium tuberculosis. The disease is more common now than in previous cases, and is associated with high rates of morbidity and mortality. The most common cause of death of HIV-AIDS patients is tuberculosis (WHO, 2016). A large number of new TB cases is increasingly resistant to drugs; this is a detrimental effect of first and second line anti-TB drugs. Because of the increased incidence of TB as a result of viral infections, there has been increased research interest aimed at the discovery of new anti-TB compounds (Lougheed et al., 2009). Specifically, the most resistant strains are resistant to the two most routinely used anti-TB drugs, rifampicin and isoniazid, and this has produced serious impacts on epidemiology and disease control (Kochi and Vareldzis, 1992).

Isoniazid, also named as isonicotinylhydrazide (INH), is a hydrazide compound derived from isonicotinic acid compound (pyridine-4-carbohydrate), and is one of the first-line drugs for tuberculosis. INH enables KatG to form the INH-nicotinamide adenine dinucleotide (NAD) adduct. This adduct inhibits the acyl carrier protein (ACP) and InhA reductase, resulting in the synthesis of type II fatty acids, which in turn will synthesize mycolic acid, causing cell death (Rodrigues et al., 2013).

Previous studies have modified isoniazid with amino azetidinones (Thomas and Harindran, 2016), pyrazoles (Vidya, 2014), oxadiazole (Malhotra et al., 2012), gelatine (Cassano et al., 2012), heteroaromatic and chloroquinoline (Ferreira et al., 2010), thiosemicarbazide (Sharma, Nagda and Talesara, 2006), 3-methoxysalicylaldehyde (Pahlavani, Kargar and Sepehri Rad, 2015), anilines (Rychtarcíková et al., 2014), via the carbonyl group, methyl salicylate (Alea, Lagua and Caparas, 2014), acylated with acyl compound (Hearn and Cynamon, 2003), azetidine (Asundaria, Patel and Patel, 2011), fatty acid hydrazide (Rodrigues et al., 2013), and using molecular hybridization with phenyl derivatives (Chollet et al., 2015).
In the study of structura-activity relationships, Ragno et al. (2000) showed that high partition coefficient $(\log \mathrm{P})$ values play an important role in antimicrobial activity because lipophilic compounds have more potent antimycobacterial potential. High $\log \mathrm{P}$ values represent an increase in drug permeability through the lipid-rich mycobacterial cell wall.

In this study, we designed and synthesized isoniazid compounds which were acylated with benzoyl chloride derivatives, thereby increasing the $\log \mathrm{P}$ value of the compounds. The interaction of the compounds with Mycobacterium tuberculosis enoyl-acyl carrier protein reductase (InhA) was computationally studied.

\section{EXPERIMENTAL}

\section{Materials}

All of the chemical reagents used in synthesis and characterization were reagent grade. The N'-benzoylisonicotinohydrazide derivatives were synthesized from the reaction of isonicotinohydrazide with the benzoyl chloride derivatives (Fig. 1). The structures of the compounds were identified using Infrared (IR) spectroscopy, ${ }^{1} \mathrm{H}$-nuclear magnetic resonance (NMR) spectroscopy, and mass spectrometry. Their purity was determined by melting point and thin layer chromatography (TLC) analysis.

\section{General experiments}

All reagents and solvents were purchased from standard commercial suppliers. Melting points were measured with an electrothermal melting point apparatus without correction. Infra red spectra were recorded in $\mathrm{KBr}$ on a Jasco FT-IR 5300, and the major absorption was recorded in $\mathrm{cm}^{-1}$. ${ }^{1} \mathrm{H}-\mathrm{NMR}$ spectra were taken on an NMR Agilent system consol DD2 spectrometer $\left({ }^{1} \mathrm{H}-\mathrm{NMR} 500 \mathrm{MHz}\right.$; ${ }^{13} \mathrm{C}-\mathrm{NMR} 125 \mathrm{MHz}$ ). MS spectra were measured with an high resolution mass spectrometry (waters LCT Premier XE, detector ESI TOF, solvent aceton $+0.1 \%$ formic acid in acetonitrile water (1:1)). 
TLC was carried out on aluminium plates coated with silica gel F254 (E Merck), using an ultra violet (UV) lamp with a wavelength of 254 $\mathrm{nm}$ for spot detection.

\section{Synthesis of $\mathrm{N}^{\prime}$-benzoylisonicotinohydrazide derivatives (a-I)}

Isonicotinohydrazide $(0.05 \mathrm{~mol})$ was mixed with triethylamine (3 $\mathrm{mL})$ in tetrahydrofuran $(20 \mathrm{~mL})$, and few drops of $0.025 \mathrm{~mol}$ benzoyl chloride in tetrahydrofuran (THF) were added slowly at room temperature. The temperature was raised to $100^{\circ} \mathrm{C}$ and the mixture was refluxed for five hours. The mixture was concentrated by evaporating THF from the mixture, and the product was washed with distilled water and then saturated with sodium bicarbonate. The resulting solid was recrystallized with hot ethanol to give the N'benzoylisonicotinohydrazide derivatives (Ruswanto et al., 2015).

\section{N'-benzoylisonicotinohydrazide (a)}

The compound was acquired with a yield of $51.71 \%$. The compound was a white crystal; m.p. range $233-233.6^{\circ} \mathrm{C}$; UV-Vis (DMSO) $\lambda_{\max }(\mathrm{nm}): 296 .{ }^{1} \mathrm{H}-\mathrm{NMR}\left(\mathrm{CHCl}_{3}-\mathrm{DD} 2,500 \mathrm{MHz}\right): \delta(\mathrm{ppm})$ 7.50-7.53 (t, $2 \mathrm{H}, J=7.5 \mathrm{~Hz}, 2 \mathrm{CH}$-aromatic.); 7.59-7.62 (t, $1 \mathrm{H}$, $J=7.25 \mathrm{~Hz}, \mathrm{CH}$-aromatic); 7.721-7.73 (dd, $4 \mathrm{H}, J=5 \mathrm{~Hz}, 4 \mathrm{CH}-$ aromatic); 7.87-7.88 (dd, $2 \mathrm{H}, J=8 \mathrm{~Hz}, 2 \mathrm{CH}$-aromatic); 8.82-8.83 (dd, $2 \mathrm{H}, J=5.5 \mathrm{~Hz}, 2 \mathrm{NH})$; IR (KBr): Umaks $\left(\mathrm{cm}^{-1}\right) 3208.96 ; 3004.55(\mathrm{~N}-$ $\mathrm{H}), 1650.77(\mathrm{C}=\mathrm{O}$ amide $), 1484.92 ; 1292.7(\mathrm{C}=\mathrm{C}$ Ar $), 748.25 ; 701.60$ (C-H mono substitution). MS m/z ESI: $242.09(\mathrm{M}+\mathrm{H})^{+}$.

\section{N'-(2-chlorobenzoyl)isonicotinohydrazide (b)}

The product was obtained with a yield of $9.79 \%$. The product was a yellow powder; m.p. range $98-100^{\circ} \mathrm{C}$; UV-Vis (DMSO) $\lambda_{\max }(\mathrm{nm})$ : 365.5. ${ }^{1} \mathrm{H}-\mathrm{NMR}\left(\mathrm{CHCl}_{3}-\mathrm{DD} 2,500 \mathrm{MHz}\right): \delta(\mathrm{ppm})$ 7.42-7.46 (m, $1 \mathrm{H}$, CH-aromatic.); 7.48-7.54 (m, 2H, 2CH-aromatic); 7.67-7.69 (d, $1 \mathrm{H}, J$ $=9.05 \mathrm{~Hz}, \mathrm{CH}$-aromatic); 7.87-7.88 (dd, $4 \mathrm{H}, J=6.146 \mathrm{~Hz}, 4 \mathrm{CH}-$ aromatic); 8.74-8.75 (dd, $2 \mathrm{H}, J=6.15 \mathrm{~Hz}, 2 \mathrm{NH})$; IR $(\mathrm{KBr})$, Umaks $\left(\mathrm{cm}^{-}\right.$ 1) $3456.44 ; 3379.29(\mathrm{~N}-\mathrm{H}), 1658.78(\mathrm{C}=\mathrm{O}$ amide $), 1519.91 ; 1489.05$ $(\mathrm{C}=\mathrm{C} \mathrm{Ar}), 1126.43 ; 1072$ (C-N amine). $756(\mathrm{C}-\mathrm{Cl}) . \mathrm{MS} \mathrm{m} / \mathrm{z}$ ESI: $276.01(\mathrm{M}+\mathrm{H})^{+}$

\section{N'-(2-fluorobenzoyl)isonicotinohydrazide (c)}

The product was obtained with a yield of $7.07 \%$. The product was a yellow powder; m.p. range $198-200^{\circ} \mathrm{C}$; UV-Vis (DMSO) $\lambda_{\max }(\mathrm{nm})$ : 356.6. ${ }^{1} \mathrm{H}-\mathrm{NMR}\left(\mathrm{CHCl}_{3}-\mathrm{DD} 2,500 \mathrm{MHz}\right): \delta(\mathrm{ppm})$ 7.24-7.29 (m, $1 \mathrm{H}$, CH-aromatic.); 7.3096-7.3504 (m, 1H, CH-aromatic); 7.57-7.63 (m, $3 \mathrm{H}, \mathrm{CH}$-aromatic); 7.87-7.88 (dd, $2 \mathrm{H}, J=6.15 \mathrm{~Hz}, 2 \mathrm{CH}$-aromatic); 8.73-8.74 (dd, $2 \mathrm{H}, J=6.1 \mathrm{~Hz}, 2 \mathrm{NH})$; IR (KBr): Umaks $\left(\mathrm{cm}^{-1}\right) 3217.27$ $(\mathrm{N}-\mathrm{H}), 1597.06(\mathrm{C}=\mathrm{O}$ amide $), 1473.62 ; 1404.18(\mathrm{C}=\mathrm{C}$ Ar $), 1288.45$; 1219.01 (CH of aromatic disubstitution). MS m/z ESI: 258.47 (M-1).

\section{N'-(4-fluorobenzoyl)isonicotinohydrazide (d)}

The product was obtained with a yield of $13.84 \%$. The product was a white crystal; m.p. range $222-224^{\circ} \mathrm{C}$; UV-Vis (DMSO) $\lambda_{\max }(\mathrm{nm})$ : 297. ${ }^{1} \mathrm{H}-\mathrm{NMR}\left(\mathrm{CHCl}_{3}-\mathrm{DD} 2,500 \mathrm{MHz}\right): \delta(\mathrm{ppm})$ 7.23-7.27 (t, $2 \mathrm{H}$, $J=7.9 \mathrm{~Hz}, \mathrm{CH}$-aromatic); $7.88-7.89(\mathrm{~d}, 2 \mathrm{H}, \mathrm{d}, J=7.7 \mathrm{~Hz}, 2 \mathrm{NH}) ; 7.98-$ $8.01(\mathrm{~m}, 4 \mathrm{H}, \mathrm{CH}$-aromatic); 8.72-8.73 (d, 2H, d, $J=4.55 \mathrm{~Hz}, 2 \mathrm{NH})$; IR (KBr): Umaks $\left(\mathrm{cm}^{-1}\right)$ : $3464.15(\mathrm{~N}-\mathrm{H}), 1666.5(\mathrm{C}=\mathrm{O}$ amide), 1515.18; 848.68 ( $\mathrm{C}=\mathrm{C}$ ar), 748.38; 648.08; 617.22 (C-H ar.). MS m/z ESI: $258.30(\mathrm{M}-1)$.

\section{N'-(3-bromobenzoyl)isonicotinohydrazide (e)}

The product was obtained with a yield of $2.09 \%$. The product was a light yellow powder; m.p. range $200-202^{\circ} \mathrm{C}$; UV-Vis (DMSO) $\lambda_{\max }$ (nm): 365.5. ${ }^{1} \mathrm{H}-\mathrm{NMR}\left(\mathrm{CHCl}_{3}-\mathrm{DD} 2,500 \mathrm{MHz}\right): \delta(\mathrm{ppm})$ 7.44-7.47 (t, $1 \mathrm{H}, J=7.9 \mathrm{~Hz}, \mathrm{CH}$-aromatic.); 7.76-7.79 $(1 \mathrm{H}, \mathrm{d}, J=11.1, \mathrm{CH}-$ aromatic); 7.87-7.88 (m, 4H, 4CH-aromatic); 8.09 (s, 1H, CHaromatic); 8.74-8.76 (d, $2 \mathrm{H}, J=6.1 \mathrm{~Hz}, 2 \mathrm{NH})$; IR $(\mathrm{KBr}):$ Umaks $\left(\mathrm{cm}^{-1}\right)$ 3410.15; $3224.98(\mathrm{~N}-\mathrm{H}), 1643.35(\mathrm{C}=\mathrm{O}$ amide $), 1558.48(\mathrm{C}=\mathrm{C}$ Ar). MS m/z ESI: 319.141 (M-1).

\section{N'-(3-chlorobenzoyl)isonicotinohydrazide (f)}

The product was obtained with a yield of $7.23 \%$. The product was a white powder; m.p. range $208-210^{\circ} \mathrm{C}$; UV-Vis (DMSO) $\lambda_{\max }(\mathrm{nm})$ : 357. ${ }^{1} \mathrm{H}-\mathrm{NMR}\left(\mathrm{CHCl}_{3}-\mathrm{DD} 2,500 \mathrm{MHz}\right): \delta(\mathrm{ppm}) 7.49-7.53(\mathrm{t}, 2 \mathrm{H}$, $J=9.75 \mathrm{~Hz}, \mathrm{CH}$-aromatic); 7.61-7.64 (d, $1 \mathrm{H}, J=11.35 \mathrm{~Hz}, \mathrm{CH}-$ aromatic); 7.85-7.88 (m, 3H, 3CH-aromatic); $7.95(\mathrm{~s}, 2 \mathrm{H}, 2 \mathrm{CH}-$ aromatic); 8.74-8.76 (dd, $2 \mathrm{H}, J=6.15 \mathrm{~Hz}, 2 \mathrm{NH}) ; \mathrm{IR}(\mathrm{KBr}): \mathrm{U}_{\text {maks }}\left(\mathrm{cm}^{-}\right.$ $\left.{ }^{1}\right)$ : $3433.29(\mathrm{~N}-\mathrm{H}), 1643.35(\mathrm{C}=\mathrm{O}$ amide $), 1543.10(\mathrm{C}=\mathrm{C}$ Ar), 756.10 (C-Cl). MS m/z ESI: 274.41 (M-1).

\section{N'-(3-nitrobenzoyl)isonicotinohydrazide (g)}

The product was obtained with a yield of $59.11 \%$. The product was a white crystal; m.p. range $194.5-195.7^{\circ} \mathrm{C}$; UV-Vis (DMSO) $\lambda_{\max }$ $(\mathrm{nm}): 365.5 .{ }^{1} \mathrm{H}-\mathrm{NMR}\left(\mathrm{CHCl}_{3}-\mathrm{DD} 2,500 \mathrm{MHz}\right): \delta(\mathrm{ppm}) 7.73-7.76(\mathrm{t}$, $1 \mathrm{H}, J=7.25 \mathrm{~Hz}, \mathrm{CH}$-aromatic.); 8.04-8.05 (d, $2 \mathrm{H}, J=4.5 \mathrm{~Hz}, 2 \mathrm{CH}-$ aromatic); 8.46-8.47 (dd, $2 \mathrm{H}, J=7.5 \mathrm{~Hz}, 2 \mathrm{CH}$-aromatic); 8.54-8.55 (dd, $1 \mathrm{H}, J=6.5 \mathrm{~Hz}, 2 \mathrm{CH}$-aromatic); 8.76 (s, 1H, CH-aromatic); 8.84$8.85(\mathrm{~d}, 1 \mathrm{H}, J=4.5 \mathrm{~Hz}, \mathrm{CH}$-aromatic); $8.89-8.90(\mathrm{~d}, 2 \mathrm{H}, J=5 \mathrm{~Hz}$, 2NH); IR (KBr): Umaks $\left(\mathrm{cm}^{-1}\right) 3220.54(\mathrm{~N}-\mathrm{H}), 1646.91(\mathrm{C}=\mathrm{O}$ amide), 1531.2; 1349.93 ( $\mathrm{C}=\mathrm{C}$ Ar), 856.24; 713.53 ; 593.96 (disubtitution of aromatic). MS m/z ESI: $286.0702(\mathrm{M}+\mathrm{H})^{+}$.

\section{N'-(4-bromobenzoyl)isonicotinohydrazide (h)}

The product was obtained with a yield of $53.25 \%$. The product was a light yellow powder; m.p. range $230-232^{\circ} \mathrm{C}$; UV-Vis (DMSO) $\lambda_{\max }$ (nm): 364.5. ${ }^{1} \mathrm{H}-\mathrm{NMR}\left(\mathrm{CHCl}_{3}-\mathrm{DD} 2,500 \mathrm{MHz}\right): \delta$ (ppm) 7.68-7.71 (dd, $2 \mathrm{H}, J=11.05 \mathrm{~Hz}, 2 \mathrm{CH}$-aromatic.); 7.83-7.84 (dd, $2 \mathrm{H}, J=4.5 \mathrm{~Hz}$, $2 \mathrm{CH}$-aromatic); 7.85-7.85 (dd, $2 \mathrm{H}, J=1.9 \mathrm{~Hz}, 2 \mathrm{CH}$-aromatic); 7.877.88 (dd, $2 \mathrm{H}, J=6.2 \mathrm{~Hz}, 2 \mathrm{CH}$-aromatic); 8.74-8.75 (dd, $2 \mathrm{H}, J=6.15$ $\mathrm{Hz}, 2 \mathrm{NH})$; IR (KBr): Umaks $\left(\mathrm{cm}^{-1}\right)$ 3425.58; $3186.40(\mathrm{~N}-\mathrm{H}), 1597.06$ ( $\mathrm{C}=\mathrm{O}$ amide), 1458.18 ( $\mathrm{C}=\mathrm{C}$ Ar). MS m/z ESI: 318.49 (M-1).

\section{N'-(4-tert-butylbenzoyl)isonicotinohydrazide (i)}

The product was obtained with a yield of $12.95 \%$. The product was a white powder; m.p. range $202-204^{\circ} \mathrm{C}$; UV-Vis (DMSO) $\lambda_{\max }(\mathrm{nm})$ : 365.5. ${ }^{1} \mathrm{H}-\mathrm{NMR}\left(\mathrm{CHCl}_{3}-\mathrm{DD} 2,500 \mathrm{MHz}\right): \delta(\mathrm{ppm}) 1.36-1.37(\mathrm{~s}, 9 \mathrm{H}$, $3\left(\mathrm{CH}_{3}\right)$; 7.54-7.57 (m, 4H, 4CH-aromatic); 7.87-7.89 (m, 4H, $4 \mathrm{CH}-$ aromatic); 8.74-8.75 (dd, $2 \mathrm{H}, J=6.15 \mathrm{~Hz}, 2 \mathrm{NH})$; IR $(\mathrm{KBr}), \mathrm{U}_{\text {maks }}\left(\mathrm{cm}^{-}\right.$ 1): $3425.58(\mathrm{~N}-\mathrm{H}), 1635.54(\mathrm{C}=\mathrm{O}$ amide $), 1481.33(\mathrm{C}=\mathrm{C}$ Ar $) . \mathrm{MS} \mathrm{m} / \mathrm{z}$ ESI: 296.73 (M-1).

\section{N'-(4-methylbenzoyl)isonicotinohydrazide (j)}

The product was obtained with a yield of $9.6 \%$. The product was a white-yellowish powder; m.p. range $200-202^{\circ} \mathrm{C}$; UV-Vis (DMSO) $\lambda_{\max }(\mathrm{nm}): 370 .{ }^{1} \mathrm{H}-\mathrm{NMR}\left(\mathrm{CHCl}_{3}-\mathrm{DD} 2,500 \mathrm{MHz}\right): \delta$ (ppm) 2.42 (s, $\left.3 \mathrm{H},-\mathrm{CH}_{3}\right) ; 7.32-7.34$ (dd, $2 \mathrm{H}, J=7.95 \mathrm{~Hz}, 2 \mathrm{CH}$-aromatic); 7.82-7.84 (dd, $2 \mathrm{H}, J=8.25 \mathrm{~Hz}, 2 \mathrm{CH}$-aromatic); 7.86-7.87 (dd, $2 \mathrm{H}, J=1.7 \mathrm{~Hz}$, $2 \mathrm{CH}$-aromatic); 7.87-7.88 (dd, $2 \mathrm{H}, J=1.7 \mathrm{~Hz}, 2 \mathrm{CH}$-aromatic); 8.73 $8.75(\mathrm{dd}, 2 \mathrm{H}, J=6.15 \mathrm{~Hz}, 2 \mathrm{NH})$; IR $(\mathrm{KBr}): \mathrm{U}_{\text {maks }}\left(\mathrm{cm}^{-1}\right) 3425.58$; $3194.12(\mathrm{~N}-\mathrm{H}), 1651.07(\mathrm{C}=\mathrm{O}$ amide $), 1543.05(\mathrm{C}=\mathrm{C}$ Ar). MS m/z ESI: $254.17(\mathrm{M}-1)$.

\section{N'-(4-chlorobenzoyl)isonicotinohydrazide (k)}

The product was obtained with a yield of $8.63 \%$. The product was a yellow powder; m.p. range $198-200^{\circ} \mathrm{C}$; UV-Vis (DMSO) $\lambda_{\max }(\mathrm{nm})$ : 364.5. ${ }^{1} \mathrm{H}-\mathrm{NMR}\left(\mathrm{CHCl}_{3}-\mathrm{DD} 2,500 \mathrm{MHz}\right): \delta(\mathrm{ppm}) 7.52-7.55(\mathrm{dd}, 2 \mathrm{H}$, $J=13.6 \mathrm{~Hz}, 2 \mathrm{CH}$-aromatic); 7.87-7.88 (dd, $2 \mathrm{H}, J=6.2 \mathrm{~Hz}, 2 \mathrm{CH}-$ aromatic); 7.90-7.91 (dd, $2 \mathrm{H}, J=4.5,2 \mathrm{CH}$-aromatic); 7.92-7.93 (dd, $2 \mathrm{H}, J=4.6 \mathrm{~Hz}, 2 \mathrm{CH}$-aromatic); 8.74-8.75 (dd, $2 \mathrm{H}, J=6.2,2 \mathrm{NH})$; IR (KBr): Umaks $\left(\mathrm{cm}^{-1}\right) 371.57 ; 3278.99(\mathrm{~N}-\mathrm{H}), 1681.93(\mathrm{C}=\mathrm{O}$ amide), 1597.6 (C=C Ar), 1226.73; 1095.57 (C-N amine). 745.35 (C-Cl). MS m/z ESI: 274.15 (M-H).

\section{N'-(3,5-dinitrobenzoyl)isonicotinohydrazide (I)}

The product was obtained with a yield of $11.88 \%$. The product was a light brown crystal; m.p. range $222-224^{\circ} \mathrm{C}$; UV-Vis (DMSO) $\lambda_{\max }$ $(\mathrm{nm}): 359 .{ }^{1} \mathrm{H}-\mathrm{NMR}\left(\mathrm{CHCl}_{3}-\mathrm{DD} 2,500 \mathrm{MHz}\right): \delta(\mathrm{ppm})$ 7.91-7.92 (dd, $2 \mathrm{H}, J=6.1 \mathrm{~Hz}, 2 \mathrm{CH}$-aromatic.); 8.68-8.69 (dd, $2 \mathrm{H}, J=6.15,2 \mathrm{CH}-$ 
aromatic); 8.97 (s, 1H, CH-aromatic); 9.22-9.23 (dd, 4H, $J=2.15 \mathrm{~Hz}$, 2NH/2CHH-aromatic); IR (KBr): Umaks $\left(\mathrm{cm}^{-1}\right) 3546.6(\mathrm{~N}-\mathrm{H}), 1597.8$ $(\mathrm{C}=\mathrm{O}$ amide), 1532.3 ( $\mathrm{N}=\mathrm{O}$ strech). 1348.8 ( $\mathrm{N}=\mathrm{O}$ bending). $\mathrm{MS} \mathrm{m} / \mathrm{z}$ ESI: $332.0633(\mathrm{M}+\mathrm{H})^{+}$.

\section{Molecular docking}

Prepared docking input files and molecular docking were performed using Autodock Tools version 1.5.6rc3. The ligands were treated as flexible, while the protein was kept rigid. Grid boxes were situated around the binding site using 5-Hexyl-2-(2methylphenoxy)phenol (TCU) as the grid box centre (-20.088, -4.456 , and -31.202). The box size was set to $26,30,32 \AA$ ( $\mathrm{x}, \mathrm{y}$, and $\mathrm{z}$, respectively) and the grid spacing to $0.375 \AA$. Docking calculations were performed using Lamarckian Genetic Algorithm (LGA) (Morris and Huey, 2009). LigPlot ${ }^{+}$v.1.4.5 was used for two dimensional

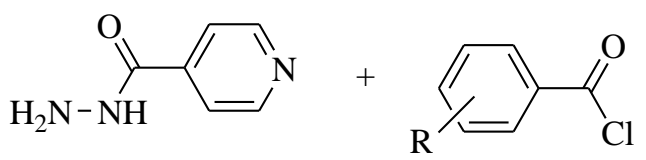

visualization (Luscombe, Laskowski and Thornton, 1997; Laskowski et al., 2011). The X-ray crystallographic structure of Mycobactarium tuberculosis enoyl-acyl carrier protein reductase (InhA) was obtained from the Protein Data Bank with PDBid: 2X23 (Luckner et al., 2010)

\section{RESULTS AND DISCUSSION}

\section{Synthesis of N'-benzoylisonicotinohydrazide derivatives}

The N'-benzoylisonicotinohydrazide derivatives (a-l), as shown in Figure 1, were synthesized from isonicotinohydrazide and benzoyl chloride in one step. The twelve compounds were white, yellow, and brown, and all of them were water insoluble substances. The structures of the compounds were identified using UV-visible, FT-IR, and ${ }^{1} \mathrm{H}-$ NMR spectroscopies, and mass spectrometry as follow:

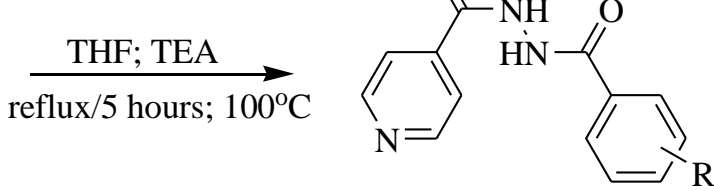

\section{$\mathrm{R}: \mathrm{a}=\mathrm{H} ; \mathrm{b}=2-\mathrm{Cl}$; $\mathrm{c}=2-\mathrm{F} ; \mathrm{d}=4-\mathrm{F} ; \mathrm{e}=3-\mathrm{Br} ; \mathrm{f}=3-\mathrm{Cl} ; \mathrm{g}=3-\mathrm{NO}_{2} ; \mathrm{h}=4-\mathrm{Br} ; \mathrm{i}=4$-tert-butyl; j= 4-CH 3 ; $\mathrm{k}=4-\mathrm{Cl}$; $1=3,5-\mathrm{diCl}$}

Fig. 1 Synthesis of the N'-benzoylisonicotinohydrazide derivatives.

The N'-benzoylisonicotinohydrazide derivatives were produced by nucleophilic acylation between benzoyl chloride derivatives and isonicotinohydrazide; the nucleophile was isonicotinohydrazide. The structural change of isonicotinohydrazide to $\mathrm{N}$ benzoylisonicotinohydrazide derivatives was characterized by the conversion of the $-\mathrm{NH}_{2}$ moiety of isonicotinohydrazide to $2(-\mathrm{N}-\mathrm{C}=\mathrm{O})$ (amide). This change could be observed in the ${ }^{1} \mathrm{H}-\mathrm{NMR}$ spectra, which showed a proton peak at the $-\mathrm{NH}$ region, and was supported by the IR spectra with NH bands.

The characteristic $\mathrm{v}(\mathrm{N}-\mathrm{H})$ stretching vibrations of $\mathrm{N}^{\prime}$ benzoylisonicotinohydrazide derivatives appeared in the 3004.55$3546.6 \mathrm{~cm}^{-1}$ range. The difference between the $\mathrm{v}(\mathrm{N}-\mathrm{H})$ stretching frequencies is due to intramolecular hydrogen bonding between $\mathrm{H}$ atom (-NH) with O atom (-C=O) (Coelho et al., 2012; Pahlavani, Kargar and Sepehri Rad, 2015). Strong absorption of the $v(C=O)$ amide bands in the IR spectra of the compounds were observed in the 1597.06-1681.93 $\mathrm{cm}^{-1}$ region; this is in a lower frequency range compared with ordinary carbonyl absorption $\left(1700 \mathrm{~cm}^{-1}\right)$. In addition to the infrared spectrum, the synthesized compounds were also confirmed by ${ }^{1} \mathrm{H}-\mathrm{NMR}$ spectroscopy and mass spectrometry.

\section{Molecular docking results}

The RpoB, InhA, ATP synthase, DprE1, and DNA Gyrace are some of drug targets for tuberculosis; for tuberculosis treatment has found the drugs which inhibited of these targets (Ghorab et al., 2017; Vilchèze and Jacobs, Jr., 2007). The most potent treatment targeting the InhA enzyme is isoniazid. Isoniazid is found to interfere with NAD-utilizing enzymes, primarily the enoyl-ACP reductase encoded by the InhA gene, leading to the arrest of mycolic acid synthesis, which is essential to M. tuberculosis (Seifert et al., 2015; Vilchèze and Jacobs, Jr., 2007). The InhA enzyme was chosen based on its hydrophobic properties, which would interact favourably with thioamide or thiourea moieties (Chollet et al., 2015).

Recently, in order to explore the possible binding modes, molecular docking of all compounds to the active site of InhA is performed to determine the possible binding site of the compounds. For this purpose, InhA is co-crystallized with 5-hexyl-2-(2-methylphenoxy)phenol (TCU) (PDBid: 2X23) (Luckner et al., 2010). The Autodock Tools version 1.5.6rc3 was used for all docking procedures. The docking protocol was tested and verified by re-docking of the co-crystallized ligand in the binding pocket of the enzyme binding affinity $=-7.52$ $\mathrm{kcal} / \mathrm{mol}$ and root mean standard deviation $(\mathrm{RMSD})=1.2285$ (Fig. 2).

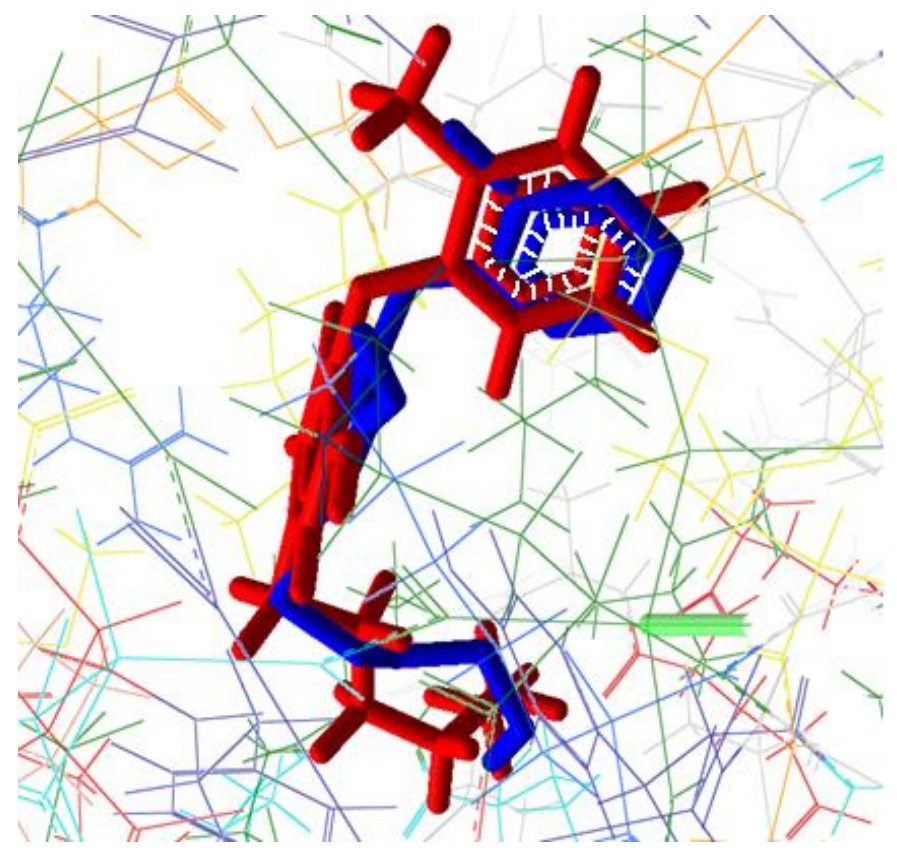

Fig. 2 Superimposition of the co-crystallized ligand (red) and the redocked ligand (blue).

The 2D and 3D ligand interactions of compound $\mathbf{g}$ (Fig. 3) demonstrated that the compound binds to the amino acid of the active site, Ile 194 through one hydrogen bond (3.28 A), Lys 165 through one hydrogen bond $(2.72 \AA)$, and Tyr 158 through one hydrogen bond $(2.63$ $\AA$ ); it has a binding affinity of $-8.17 \mathrm{kcal} / \mathrm{mol}$. All binding affinity data can be found in Table 1 .

Based on Table 1, it was evident that all of the $\mathrm{N}^{\prime}$ benzoylisonicotinohydrazide derivatives (a-l) have binding affinities and predicted inhibition constant better than isoniazid. Thus, the compounds (a-l) are predicted to have good interaction with the InhA active site, and the best predicted binding is observed for compound $\mathbf{g}$ (Kartasasmita et al., 2009; Khokra et al., 2016). 


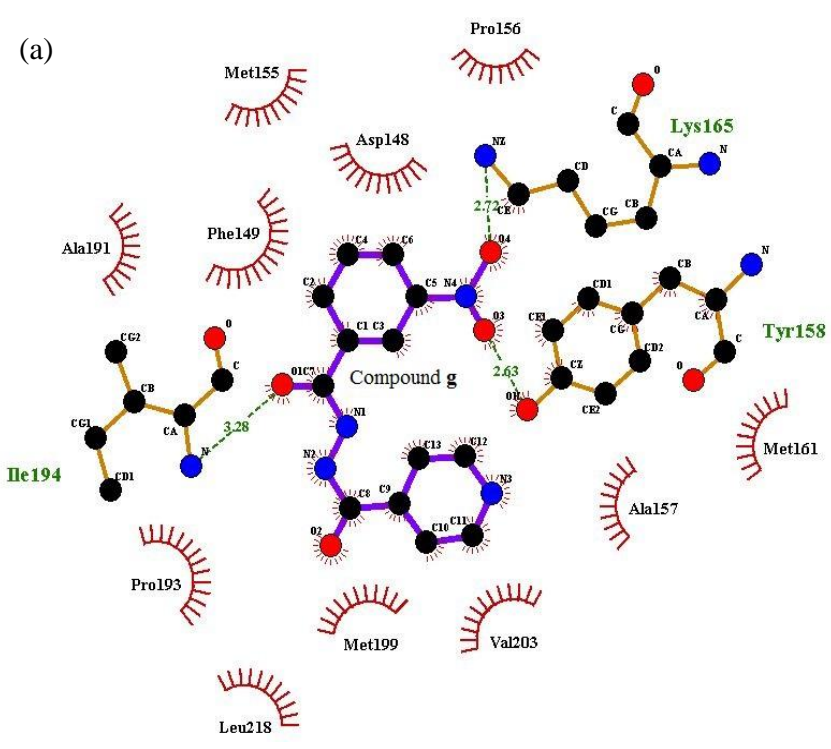

(b)

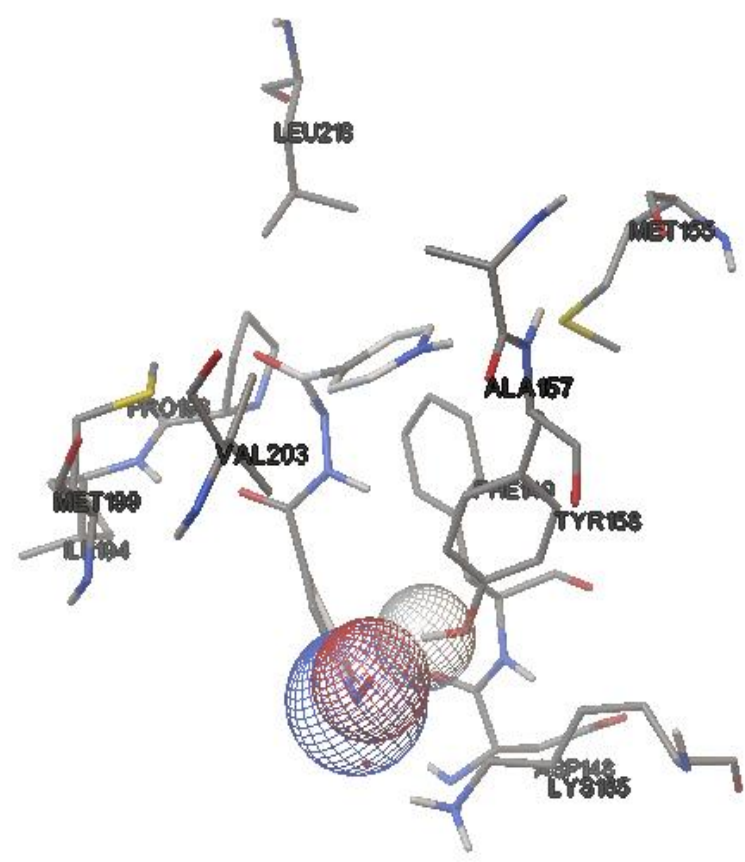

Fig. 3 The 2D visualization (a) and 3D visualization (b), of compound $\mathbf{g}$ in the InhA active site.

Table 1. Docking results of the compounds inside the $\operatorname{lnh} A$ active site.

\begin{tabular}{|c|c|c|}
\hline Compound & $\begin{array}{l}\text { Binding affinity } \\
\text { (kcal } / \mathrm{mol})\end{array}$ & $\begin{array}{l}\text { Predicted inhibition } \\
\text { constant }(\mu \mathrm{M})\end{array}$ \\
\hline Isoniazid & $\begin{array}{l}-7.52 \\
-5.91 \\
-6.13 \\
-5.72 \\
-6.20 \\
-6.76 \\
-6.92 \\
-8.17 \\
-6.64 \\
-6.84 \\
-6.25 \\
-6.44 \\
-7.61 \\
-4.64\end{array}$ & $\begin{array}{c}3.06 \\
46.33 \\
32.08 \\
64.12 \\
28.31 \\
11.06 \\
8.54 \\
1.02 \\
13.67 \\
9.61 \\
26.43 \\
19.15 \\
2.63 \\
398.64\end{array}$ \\
\hline
\end{tabular}

\section{CONCLUSION}

New series of N'-benzoylisonicotinohydrazide compounds (a-l) were synthesized by alcylating reactions between isonicotinohydrazide and benzoyl chloride derivatives, using the reflux method. The target compounds were designed and synthesized as potential antituberculosis compounds. Docking results revealed that all of the compounds were bound well to InhA, with compound $\mathbf{g}$ exhibited the best binding affinity $(-8.17 \mathrm{kcal} / \mathrm{mol})$ and inhibition constant value $(1.02 \mu \mathrm{M})$. Therefore, compound $\mathbf{g}$ can be used as an anti-tuberculosis candidate.

\section{ACKNOWLEDGEMENTS}

The authors would like to thank the Ministry of Research, Technology and Higher Education (Indonesia) for a Fundamental Research Grant in 2017, and Bakti Tunas Husada of Health Science College Tasikmalaya for the provision of the facilities to complete our research

\section{REFERENCES}

Alea, G. V., Lagua, F. M. G., Caparas, M. N. S. 2014. Synthesis and characterization of methyl-2-hydroxy-5-\{(1)-1-[2- (pyridin-4-ylcarbonyl) hydrazinylidene]butyl $\}$ benzoate, a new isonicotinoylhydrazone derivative of methyl salicylate. Presented at the DLSU Research Congress 2014. De La Salle University, Manila, Philippines. March, 6-8, 2014, pp. $1-5$.

Asundaria, S. T., Patel, N. S. and Patel, K. C. 2011. Synthesis, characterization, and antimicrobial studies of novel 1,3,4-thiadiazolium-5-thiolates. Medicinal Chemistry Research, 21(7), 1199-1206. doi: 10.1007/s00044011-9632-2.

Cassano, R., Trombino, S., Ferrarelli, T., Cavalcanti, P., Giraldi, C., Lai, F., Loy, G., Picci, N. 2012. Synthesis, characterization and in-vitro antitubercular activity of isoniazid-gelatin conjugate. Journal of Pharmacy and Pharmacology, 64(5), 712-718. doi: 10.1111/j.2042-7158.2012.01461.x.

Chollet, A., Mori, G., Menendez, C., Rodriguez, F., Fabing, I., Pasca, M.R., Madacki, J., Korduláková, J., Constant, P., Quémard, A., BernardesGénisson, V., Lherbet, C., Baltas, M. 2015. Design, synthesis and evaluation of new GEQ derivatives as inhibitors of InhA enzyme and Mycobacterium tuberculosis growth, European Journal of Medicinal Chemistry, 101, 218-235. doi: 10.1016/j.ejmech.2015.06.035.

Coelho, T. S., Cantos, J. B., Bispo, M. L. F., Gonçalves, R. S. B., Lima, C. H. S., da Silva, P. E. A., Souza, M. V. N. 2012. In vitro anti-mycobacterial activity of (E)-N'-(monosubstituted-benzylidene) isonicotinohydrazide derivatives against isoniazidresistant strains. Infectious Disease Reports, 4(1), 49-51. doi: 10.4081/idr.2012.e13.

Ferreira, M. de L., Gonçalves, R. S. B., Cardoso, L. N. de F., Kaiser, C. R., Candéa, A. L. P., Henriques, M. das G. M. de O., Lourenço, M. C. S., Bezerra, F. A. F. M., de Souza, M. V. N. 2010. Synthesis and antitubercular activity of heteroaromatic isonicotinoyl and 7-chloro-4quinolinyl hydrazone derivatives. The Scientific World Journal, 10, 1347-1355. doi: 10.1100/tsw.2010.124.

Ghorab, M. M., El-Gaby, M. S. A., Soliman, A. M., Alsaid, M. S., Abdel-Aziz, M. M., Elaasser, M. M. 2017. Synthesis, docking study and biological evaluation of some new thiourea derivatives bearing benzenesulfonamide moiety. Chemistry Central Journal. Springer International Publishing, 11(1), p. 42. doi: 10.1186/s13065-017-0271-7.

Hearn, M. and Cynamon, M. 2003. In vitro and in vivo activities of acylated derivatives of isoniazid against mycobacterium tuberculosis. Drug Design and Discovery, 18(4), 103-108. doi: 10.1080/ 10559610390450705 .

Kartasasmita, R. E., Herowati, R., Harmastuti, N., Gusdinar, T. 2009. Quercetin derivatives docking based on study of flavonoids interaction to cyclooxygenase-2, Indonesian Journal of Chemistry, 9(2), 297-302.

Khokra, S. L., Jyoti, C. K. P., Alam, M. M., Zaman, M. S., Ahmad, A., Khan, S. A., Husain, A. 2016. Quinoline based furanones and their nitrogen analogues: Docking, synthesis and biological evaluation. Saudi Pharmaceutical Journal, 24(6), 705-717. doi: 10.1016/j.jsps. 2015.05.002.

Kochi, A. and Vareldzis, B. I. 1992. Multidrug-resistant tuberculosis and its control, Research in Microbiology, 144(2), 104-110.

Laskowski, R. A., Swindells, M. B. 2011. LigPlot+: Multiple ligand a protein interaction diagrams for drug discovery. Journal of Chemical Information and Modeling, 51(10), 2778-2786.

Lougheed, K. E. A., Taylor, D. L., Osborne, S. A., Bryans, J. S., Buxton, R. S 2009. New anti-tuberculosis agents amongst known drugs. Tuberculosis, 
89(5), 364-370. doi: 10.1016/j.tube.2009.07.002.

Luckner, S. R., Liu, N., Am Ende, C. W., Tonge, P. J., Kisker, C. 2010. A slow, tight binding inhibitor of InhA, the enoyl-acyl carrier protein reductase from Mycobacterium tuberculosis. Journal of Biological Chemistry, 285(19), 14330-14337. doi: 10.1074/jbc.M109.090373.

Luscombe, N. M., Laskowski, R. A. and Thornton, J. M. 1997. NUCPLOT: A program to generate schematic diagrams of protein-nucleic acid interactions. Nucleic Acids Research, 25(24), 4940-4945. doi: 10.1093/nar/25.24.4940.

Malhotra, M., Arora, M., Samad, A., Sahu, K., Phogat, P., Deep, A. 2012 Synthesis and evaluation of some novel derivatives of 2 propoxybenzylideneisonicotinohydrazide for their potential antimicrobia activity. Journal of the Serbian Chemical Society, 77(5), 589-597. doi: 10.2298/JSC110310170M.

Morris, G.M., Huey, R., Lindstrom, W., Sanner, M.F., Belew, R.K., Goodsell, D.S., Olson, A.J. 2009. AutoDock4 and AutoDockTools4: Automated docking with selective receptor flexibility. Journal of Computational Chemistry, 30(16), 2785-2791. doi: 10.1002/jcc.21256.AutoDock4.

Pahlavani, E., Kargar, H. and Sepehri Rad, N. 2015. A study on antitubercular and antimicrobial activity of isoniazid derivative. Zahedan Journal of Research in Medical Sciences, 17(7), 3-6. doi: 10.17795/zjrms 1010.

Ragno, R., Marshall, G. R., Di Santo, R., Costi, R., Massa, S., Rompei, R. Artico, M. 2000. Antimycobacterial pyrroles: Synthesis, antiMycobacterium tuberculosis activity and QSAR studies. Bioorganic and Medicinal Chemistry, 8(6), 1423-1432. doi: 10.1016/S0968 0896(00)00061-4.

Rodrigues, M. O., Cantos, J. B., D’Oca, C. R. M., Soares, K. L., Coelho, T. S. Piovesan, L. A., Russowsky, D., Da Silva, P. A., D’Oca, M. G. M. 2013. Synthesis and antimycobacterial activity of isoniazid derivatives from renewable fatty acids. Bioorganic and Medicinal Chemistry. 21(22), 6910-6914. doi: 10.1016/j.bmc.2013.09.034.
Ruswanto, Mardhiah, Mardianingrum, R., Novitriani, K. 2015. Sintesis dan studi in silico senyawa 3-nitro-N'-[(Pyridin-4-Yl)carbonyl] benzohydrazide sebagai kandidat antituberkulosis. Chimica et Natura Acta, 3(2), 54-61. doi: 10.24198/cna.v3.n2.9183.

Ruswanto, Miftah, A. M., Tjahjono, D. H., Siswandono. 2015. Synthesis and in vitro cytotoxicity of 1-benzoyl-3-methyl thiourea derivatives. Procedia Chemistry, 17, 157-161. doi: 10.1016/j.proche.2015.12.105.

Rychtarcíková, Z., Krátký, M., Gazvoda, M., Komlóová, M., Polanc, S., Kocevar, M., Stolaríková, J., Vinšová, J. 2014. N-substituted 2isonicotinoylhydrazinecarboxamides-new antimycobacterial active molecules. Molecules, 19(4), 3851-3868. doi: 10.3390/molecules 19043851.

Seifert, M., Catanzaro, D., Catanzaro, A., Rodwell, T.C. 2015. Genetic mutations associated with isoniazid resistance in Mycobacterium tuberculosis: A systematic review. PLoS ONE, 10(3), 1-13. doi: 10.1371/journal.pone.0119628.

Sharma, R., Nagda, D. P. and Talesara, G. L. 2006. Synthesis of various isoniazidothiazolidinones and their imidoxy derivatives of potential biological interest. Arkivoc, 2006(i), 1-12.

Thomas, B., and Harindran, J. 2016. Design, synthesis and evaluation of antitubercular activity of amino azetidinones from isoniazid. International Journal of Pharmaceutical Sciences and Research, 7(7), 2795-2804. doi: 10.13040/IJPSR.0975-8232.7(7).2795-04.

Vidhya, K. R., and Shafi, S. S.. 2014. Synthesis, characterization and antimicrobial studies of novel 2-Pyrazoline derivatives. International Journal of ChemTech Research, 6(4), 2558-2563.

Vilchèze, C., and Jacobs, W. R. Jr. 2007. The mechanism of isoniazid killing: Clarity through the scope of genetics. Annual Review of Microbiology, 61(1), 35-50. doi: 10.1146/annurev.micro.61.111606.122346.

WHO. 2016. Global tuberculosis report 2016. World Health Organization. 214 $\mathrm{pp}$ 